INSCRUTABLE BELONGINGS 
This page intentionally left blank 
A S I A N A M E R I C A

A series edited by Gordon H. Chang

The increasing size and diversity of the Asian American population, its growing significance in American society and culture, and the expanded appreciation, both popular and scholarly, of the importance of Asian Americans in the country's present and past-all these developments have converged to stimulate wide interest in scholarly work on topics related to the Asian American experience. The general recognition of the pivotal role that race and ethnicity have played in American life, and in relations between the United States and other countries, has also fostered the heightened attention.

Although Asian Americans were a subject of serious inquiry in the late nineteenth and early twentieth centuries, they were subsequently ignored by the mainstream scholarly community for several decades. In recent years, however, this neglect has ended, with an increasing number of writers examining a good many aspects of Asian American life and culture. Moreover, many students of American society are recognizing that the study of issues related to Asian America speak to, and may be essential for, many current discussions on the part of the informed public and various scholarly communities.

The Stanford series on Asian America seeks to address these interests. The series will include works from the humanities and social sciences, including history, anthropology, political science, American studies, law, literary criticism, sociology, and interdisciplinary and policy studies.

A full list of titles in the Asian America series can be found online at www.sup.org/asianamerica 
This page intentionally left blank 


\title{
INSCRUTABLE BELONGINGS
}

QUEER ASIAN NORTH AMERICAN FICTION

\author{
STEPHEN HONG SOHN
}

STANFORD UNIVERSITY PRESS - STANFORD, CALIFORNIA 
Stanford University Press

Stanford, California

(C)2018 by the Board of Trustees of the Leland Stanford Junior University. All rights reserved.

No part of this book may be reproduced or transmitted in any form or by any means, electronic or mechanical, including photocopying and recording, or in any information storage or retrieval system without the prior written permission of Stanford University Press.

Printed in the United States of America on acid-free, archival-quality paper

Library of Congress Cataloging-in-Publication Data

Names: Sohn, Stephen Hong, author.

Title: Inscrutable belongings : queer Asian North American fiction / Stephen Hong Sohn.

Other titles: Asian America.

Description: Stanford, California : Stanford University Press, 2018.

Series: Asian America | Includes bibliographical references and index.

Identifiers: LCCN 2017046518 | ISBN 9781503604018 (cloth : alk. paper) |

ISBN 9781503605923 (pbk.) | ISBN 9781503605930 (epub)

Subjects: LCSH: Gays' writings, American-History and criticism. | Gays' writings, CanadianHistory and criticism. | American fiction-Asian American authors-History and criticism.

Canadian fiction-Asian authors-History and criticism. | American fiction-21st century-

History and criticism. | Canadian fiction-21st century-History and criticism. | Asian Americans in literature. | Families in literature. | Gays in literature.

Classification: LCC PS153.G38 S64 2018 | DDC 813/.5409895-dc23

LC record available at https://lccn.loc.gov/2017046518

Typeset by Bruce Lundquist in 10/14 Minion Pro 